\title{
Use of a Tn5-based transposon system to create a cost-effective Zymomonas mobilis for ethanol production from lignocelluloses
}

\author{
Xi Zhang ${ }^{1 \dagger}$, Tianyv Wang ${ }^{2 \dagger}$, Wen Zhou ${ }^{3 \dagger}$, Xianghui Jia ${ }^{1+}$ and Haoyong Wang ${ }^{1 *}$
}

\begin{abstract}
Background: Current methods of ethanol production from lignocelluloses generate a mixture of sugars, primarily glucose and xylose; the fermentation cells are always exposed to stresses like high temperature and low nutritional conditions that affect their growth and productivity. Stress-tolerant strains capable of using both glucose and xylose to produce ethanol with high yield are highly desirable.

Results: A recombinant Zymomonas mobilis (Z. mobilis) designated as HYMX was constructed by integrating seven genes (Pfu-sHSP, yfdZ, metB, xylA, xylB, tktA and talB) into the genome of Z. mobilis CP4 (CP4) via Tn5 transposon in the present study. The small heat shock protein gene (Pfu-sHSP) from Pyrococcus furious (P. furious) was used to increase the heat-tolerance, the $y f d Z$ and met $B$ genes from $E$. coli were used to decrease the nutritional requirement. To overcome the bottleneck of CP4 being unable to use pentose, xylose catabolic genes $(x y|A, x y| B$, tktA and talB) from E. coli were integrated into CP4 also for construction of the xylose utilizing metabolic pathway.

Conclusions: The genomic integration confers on Z. mobilis the ability to grow in medium containing xylose as the only carbon source, and to grow in simple chemical defined medium without addition of amino acid. The HYMX demonstrated not only the high tolerance to unfavorable stresses like high temperature and low nutrient, but also the capability of converting both glucose and xylose to ethanol with high yield at high temperature. What's more, these genetic characteristics were stable up to 100 generations on nonselective medium. Although significant improvements were achieved, yeast extract is needed for ethanol production.
\end{abstract}

Keywords: Zymomonas mobilis, Heat shock protein, yfdZ, metB, Xylose fermentation, Ethanol production

\section{Introduction}

Among various ethanol-producing microbes, the gramnegative bacterium $Z$. mobilis is an efficient ethanol producer with favorable features that are at least equal to those from the more familiar brewer's yeast [1,2]. Ethanol production at high temperature has received much attention because fermentation processes conducted at elevated temperatures will significantly reduce cooling costs and improve simultaneous saccharification, fermentation, distillation and suitability for use in tropical countries. However, the temperatures suitable for $Z$.

\footnotetext{
* Correspondence: haoyongw@163.com

${ }^{\dagger}$ Equal contributors

'Key Laboratory of Fermentation Engineering (Ministry of Education), Hubei Provincial Key Laboratory of Industrial Microbiology, College of

Bioengineering, Hubei University of Technology, Wuhan 430068, China

Full list of author information is available at the end of the article
}

mobilis are relatively low $\left(25\right.$ to $\left.32^{\circ} \mathrm{C}\right)$. Z. mobilis is unable to produce ethanol effectively under temperature above $38^{\circ} \mathrm{C}$. Creation of the heat-tolerance strains will be of great value for the ethanol industry, while screens for recombinant $Z$. mobilis mutants able to produce ethanol efficiently at high temperature have never been performed before.

The hyperthermophilic archaeon P. furiosus expresses a small, $\alpha$-crystallin-like protein in response to extreme temperatures above $103^{\circ} \mathrm{C}$. This small heat shock protein (Pfu-sHSP) gives cellular protections from extremely high temperatures $[3,4]$ like the $\alpha$-crystallin eye lens protein, acts as molecular chaperone and prevents aggregation of denatured proteins under heat stress. It can prevent E. coli cellular proteins from aggregation above $100^{\circ} \mathrm{C}$, and can significantly enhance the viability of 
mesophilic organisms such as E. coli under lethal temperatures [4]. The introducing of the gene Pfu-sHSP might be able to protect the mesophilic enzymes of $Z$. mobilis from aggregation at elevated temperatures to increase its ethanol production under heat-stress.

The growth of $Z$. mobilis usually requires complex rich medium containing yeast extract, has long been known to require lysine and methionine $[5,6]$. The wholegenome sequencing has revealed the specific reasons for these deficiencies. The only genes missing for lysine and methionine synthesis are $y f d Z$ and $m e t B$, respectively [6-8]. The $y f d Z$ and met $B$ genes encode a PLP-dependent aminotransferase and a PLP (pyridoxal phosphate)dependent cystathionine gamma-synthase, respectively. As the $Z$. mobilis suffered from malnutrition may not be able to maintain its normal ability to produce ethanol in low nutritional conditions which are common at the end of a batch, and rich medium will significantly increase the cost of ethanol production, $y f d Z$ and $m e t B$ genes were introduced into $Z$. mobilis in this research to verify whether or not we can get a mutant $Z$. mobilis with lower nutritional requirements.

Current methods for pretreatment of lignocelluloses for ethanol production generate a mixture of pentose (C5) and hexose (C6) sugars. It has already been proved that the heterologous xylose metabolic enzymes (xylose isomerase- $x y l A$, xylulokinase- $x y l B$, transaldolase- $t k t A$, and transketolase-talB) from E. coli can be expressed in $Z$. mobilis to enable the bacteria to ferment xylose $[9,10]$. U.S. Pat. No. 5,514,583 discloses a plasmid transformed $Z$. mobilis with the ability to ferment xylose (CP4/pZB4 and pZB5), having plasmid vectors (pZB4 and pZB5) encoding $x y l A, x y l B, t k t A$ and talB exogenous genes from $E$. coli, and further comprising at least one promoter (PGAP and PENO) recognized by $Z$. mobilis which regulates the expression of at least one of the said genes. The strain is capable of growing on $x y-$ lose as the sole carbon source and fermenting xylose to ethanol at about $88 \%$ of the maximum theoretical yield. By transforming the plasmid encoding $x y l A, x y l B, t k t A$ and $t a l B$ exogenous genes from $E$. coli, they succeeded in getting a xylose-fermenting Zymomonas.

To overcome the instability limitations of foreign plasmids exhibited under both selective and non-selective conditions which are generally perceived as undesirable for industrial applications, Tn5 transposition mutagenesis in Z. mobilis was used in this research. Tn5 transposon can mediate genome DNA rearrangements and integrations of foreign DNA via a cut-and-paste mechanism. The only macromolecular components required for this process are the transposase; the transposon, which can presumably be any sequence that is defined by two specific inverted 19 bp sequences; and the target DNA into which the insertions are made [11].
Mediated by Tn 5 transposon, foreign genes were integrated into the genome of $\mathrm{CP} 4$ in this study. The $P f u$ $s H S P$ gene was used for increasing the tolerance to high temperature; the $y f d Z$ and met $B$ genes were used for increasing the tolerance to low nutrient. Xylose catabolic genes ( $x y l A, x y l B, t k t A$ and $t a l B)$ were used for adding a new metabolic pathway for the mutate CP4 to utilize xylose to produce ethanol. The study showed that the stable integration of seven foreign genes at the same time was possible, and the mutant $H Y M X$ demonstrated the capability of converting mixed sugars to ethanol with high yield, demonstrated also a high tolerance to heat stress and low nutrient stress.

\section{Results}

\section{An obvious decrement in nutritional requirement}

Although possesses a complete set of genes for synthesis of all amino acids, Z. mobilis do not have one gene in the lysine $(y f d Z)$ pathway and one gene in the methionine (metB) pathway [6,8]. Wild type Z. mobilis CP4 can grow well in medium containing yeast extract, but can not grow in simple chemical medium and in medium with xylose as the sole carbon source because it has no xylose metabolic pathway.

With the $y f d Z$ and metB genes, the $H Y M$ and $H Y M X$ strains showed normal growth in simple chemical medium both at $32^{\circ} \mathrm{C}$ and $42^{\circ} \mathrm{C}$. With the xylose catabolic genes ( $x y l A, x y l B, t k t A$ and talB) together with $y f d Z$ and metB genes from E. coli, HYMX strain showed normal growth in medium when xylose was the sole carbon source. HYMX could grow in simple chemical defined medium, as well as in medium when xylose was the sole carbon source. In contrast, neither in simple chemical defined medium nor in medium when xylose as the sole carbon source, could CP4 grow (Figure 1, Table 1).

When cultured in RM medium $(10 \mathrm{~g} / \mathrm{L}$ yeast extract, $1 \mathrm{~g} / \mathrm{L} \mathrm{KH}_{2} \mathrm{PO}_{4}, 1 \mathrm{~g} / \mathrm{L}$ Carbamide, $0.5 \mathrm{~g} / \mathrm{L} \mathrm{MgSO}_{4} \cdot 6 \mathrm{H}_{2} \mathrm{O}$ ) with $230 \mathrm{~g} / \mathrm{L}$ glucose as carbon source. After 60 hours fermentation, the ethanol concentration of $H Y M X 3$ was $98.7 \mathrm{~g} / \mathrm{L}$ (theoretical yield $83.5 \%$ ), while the ethanol concentrations of $H Y M$ and $C P 4$ was $87.1 \mathrm{~g} / \mathrm{L}$ and $78.4 \mathrm{~g} / \mathrm{L}$, respectively (Figure 2). The effects of yeast extract on ethanol production of three kinds of $Z$. mobilis strains were studied also in this research. In medium $(1 \mathrm{~g} / \mathrm{L}$ $\mathrm{KH}_{2} \mathrm{PO}_{4}, 1 \mathrm{~g} / \mathrm{L}$ Carbamide, $0.5 \mathrm{~g} / \mathrm{L} \mathrm{MgSO}_{4} \cdot 6 \mathrm{H}_{2} \mathrm{O}$ ) with $230 \mathrm{~g} / \mathrm{L}$ glucose as carbon source under anaerobic conditions at $32^{\circ} \mathrm{C}$, when the yeast extract concentration changed from 0 to $4 \mathrm{~g} / \mathrm{L}$, there were no obviously differences of ethanol yield between 3 strains. When the yeast extraction concentration changed from $4 \mathrm{~g} / \mathrm{L}$ to $8 \mathrm{~g} / \mathrm{L}$, after 60 hours fermentation, the ethanol concentration of $H Y M X 3, H Y M$ and $C P 4$ was increased by $60.4 \mathrm{~g} / \mathrm{L}, 54.5 \mathrm{~g} / \mathrm{L}$ and $39.6 \mathrm{~g} / \mathrm{L}$, respectively. From the trend lines, we can 


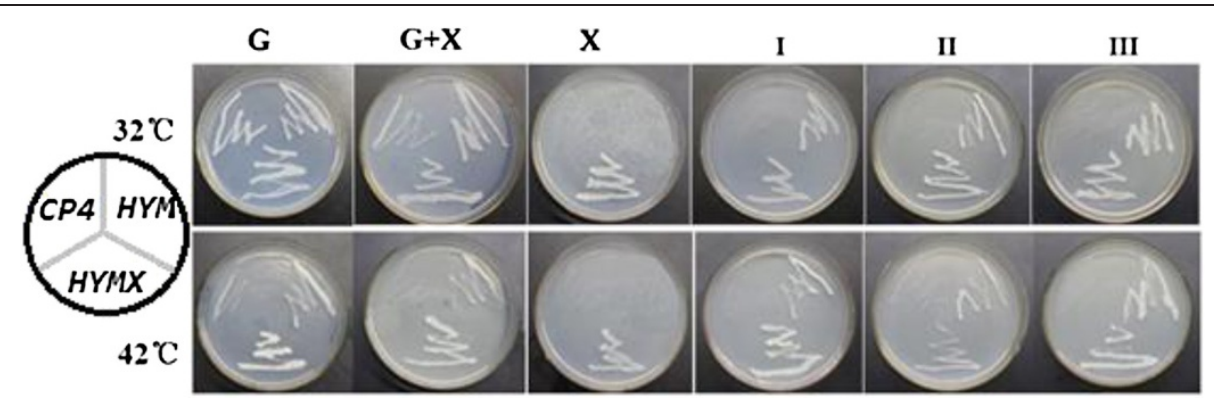

Figure 1 The growth properties of CP4, HYM and HYMX on simple chemical medium supplemented with yeast extract or without yeast extract. All strains were obtained by centrifugal sedimentation method. The same weight wet cells were washed by ultrapure water for three times before being inoculated, then all petri dishes were kept at $32^{\circ} \mathrm{C}$ or $42^{\circ} \mathrm{C}$ for 60 hours. CP4 grows well in medium (Table 1) contain yeast extract and glucose (plate $G$, plate $G+X$ ); can't grow in simple chemical medium without yeast extract (plate I, plate II and plate III) and in medium contain yeast extract with xylose as the only carbon source (plate X). HYM and HYMX can grow in simple chemical medium without yeast extract (plate I, plate II and plate III). HYMX can grow also in medium when xylose as the only carbon source (plate X).

deduce that in low nutrient medium, $H Y M X 3$ was more effective to produce ethanol than others (Figure 3).

\section{High yield fermentation of xylose and glucose}

Theoretically, 100 grams of glucose will produce 51.4 grams of ethanol and 48.6 grams of carbon dioxide. Xylose is the second most abundant carbohydrate in nature, the theoretical yield of ethanol from xylose is defined as 51.1 grams of ethanol per 100 grams of xylose $(5 \mathrm{~mol}$ of ethanol $/ 3 \mathrm{~mol}$ of xylose). However, in practice, the microorganisms use some of the sugar for growth and the actual yield is less than $100 \%$.

From all the mutants developed, four $X U$ strains and four $H Y M X$ strains were chosen for further fermentation research with $C P 4$ as a control. Strains $X U$ have stable insertion of 4 foreign structural genes $(x y l A / x y l B$ and $t a l B / t k t A$ from $E$. coli) and strains $H Y M X$ have stable insertion of 7 foreign structural genes $(x y l A, x y l B, t a l B, t k t A$, metB, $y f d Z$

Table 1 Different raw materials used for creation of the experimental growth medium (g/L)

\begin{tabular}{|c|c|c|c|c|c|c|}
\hline Plate name & G & $\mathbf{G}+\mathbf{X}$ & $X$ & I & II & III \\
\hline Yeast extract & 10.0 & 10.0 & 10.0 & 0 & 0 & 0 \\
\hline $\mathrm{KH}_{2} \mathrm{PO}_{4}$ & 1.0 & 1.0 & 1.0 & 1.0 & 1.0 & 1.0 \\
\hline $\mathrm{MgSO}_{4} \cdot 6 \mathrm{H}_{2} \mathrm{O}$ & 1.0 & 1.0 & 1.0 & 0 & 0 & 0 \\
\hline Carbamide & 1.0 & 1.0 & 1.0 & 1.0 & 0 & 1.0 \\
\hline Glucose & 10.0 & 5.0 & 0 & 10.0 & 10.0 & 10.0 \\
\hline $\mathrm{NH}_{4} \mathrm{Cl}$ & 0 & 0 & 0 & 0 & 10.0 & 0 \\
\hline $\mathrm{MgCl}_{2} \cdot 6 \mathrm{H}_{2} \mathrm{O}$ & 0 & 0 & 0 & 0 & 1.0 & 1.0 \\
\hline Xylose & 0 & 5.0 & 5.0 & 0 & 0 & 0 \\
\hline $\mathrm{NaCl}$ & 0 & 0 & 0 & 0 & 8.0 & 8.0 \\
\hline $\mathrm{CaCl}_{2} \cdot 2 \mathrm{H}_{2} \mathrm{O}$ & 0 & 0 & 0 & 0 & 0.4 & 0.4 \\
\hline $\mathrm{KCl}$ & 0 & 0 & 0 & 0 & 1.0 & 1.0 \\
\hline Agar & 20.0 & 20.0 & 20.0 & 20.0 & 20.0 & 20.0 \\
\hline
\end{tabular}

from E. coli and Pfu-sHSP from P. furiosus) into the $Z$. mobilis CP4 genome.

Z. mobilis CP4 can not grow in the medium $(10 \mathrm{~g} / \mathrm{L}$ yeast extract, $1 \mathrm{~g} / \mathrm{L} \mathrm{KH}_{2} \mathrm{PO}_{4}, 1 \mathrm{~g} / \mathrm{L}$ Carbamide, $0.5 \mathrm{~g} / \mathrm{L}$ $\mathrm{MgSO}_{4} \cdot 6 \mathrm{H}_{2} \mathrm{O}$ ) containing xylose as the sole carbon source, while the recombinant strains $X U(1 \sim 4)$ and $H Y M X(1 \sim 4)$ can grow and produce ethanol with high yield. As was shown in Figure 4 when xylose $(60 \mathrm{~g} / \mathrm{L})$ was the only carbon source, HYMX $(1 \sim 4)$ and $X U(1 \sim 4)$ were able to ferment xylose to produce ethanol. After 60 hours fermentation, the highest ethanol concentration of $X U(1 \sim 4)$ was $24.1 \mathrm{~g} / \mathrm{L}$ (theoretical yield 78.6\%). The highest ethanol concentration of HYMX (1 4) was $24.9 \mathrm{~g} / \mathrm{L}$ (theoretical yield $81.2 \%$ ). In the mixed sugar

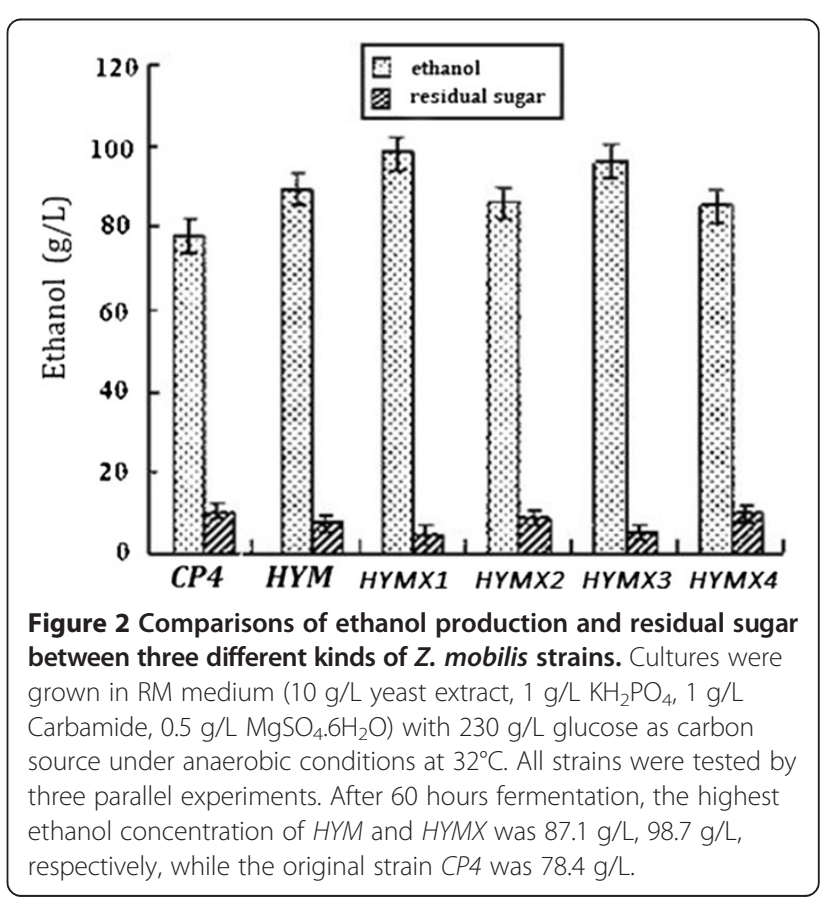




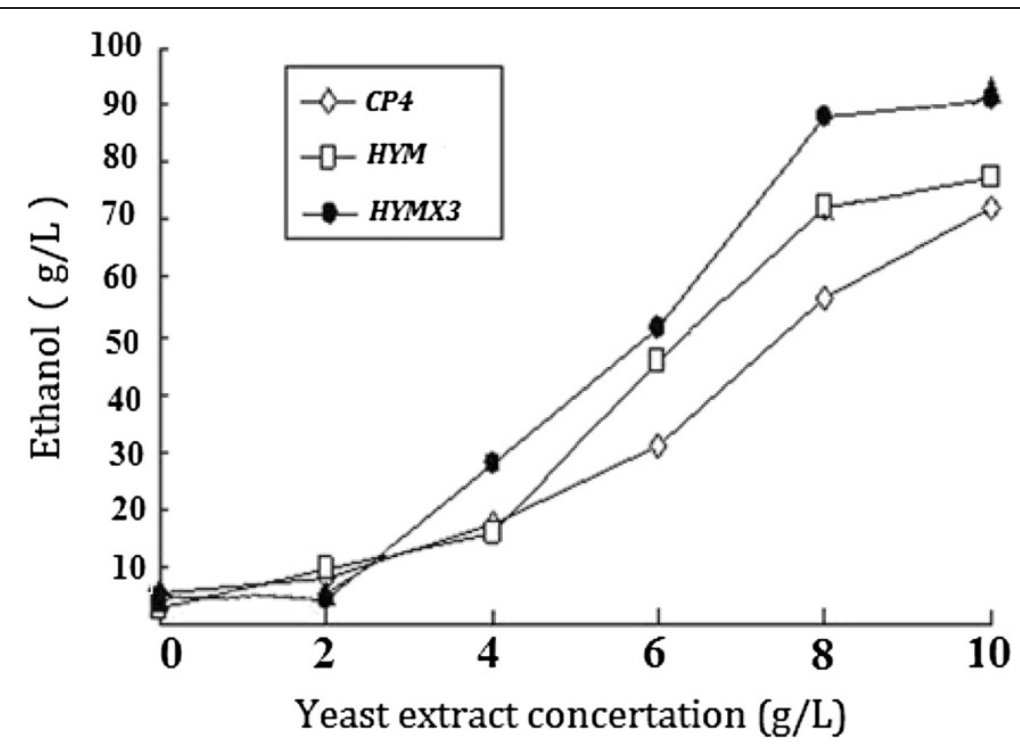

Figure 3 Comparisons of ethanol production between three kinds of $Z$. mobilis strains in medium with different concentration of yeast extract. Strains were grown in medium $\left(1 \mathrm{~g} / \mathrm{L} \mathrm{KH}_{2} \mathrm{PO}_{4}, 1 \mathrm{~g} / \mathrm{L}\right.$ Carbamide, $\left.0.5 \mathrm{~g} / \mathrm{L} \mathrm{MgSO}{ }_{4} \cdot 6 \mathrm{H}_{2} \mathrm{O}\right)$ with $230 \mathrm{~g} / \mathrm{L}$ glucose as carbon source, supplemented with different amounts of yeast extract (as indicated) under anaerobic conditions at $32^{\circ} \mathrm{C}$. All strains were tested by three parallel experiments. After 60 hours fermentation, ethanol production of all strains was measured immediately by GC.

medium (containing $170 \mathrm{~g} / \mathrm{L}$ glucose and $60 \mathrm{~g} / \mathrm{L}$ xylose) after 60 hours fermentation, the average ethanol concentration of CP4 was $72.7 \mathrm{~g} / \mathrm{L}$ (theoretical yield 61.6\%); the average ethanol concentration of XU1 was $83.8 \mathrm{~g} / \mathrm{L}$ (theoretical yield $71.0 \%$, which was $11.5 \%$ higher than $C P 4$.
While the average ethanol concentration of $H Y M X 3$ was $88.9 \mathrm{~g} / \mathrm{L}$ (theoretical yield $75.3 \%$ ), which was $22.3 \%$ higher than CP4 (Figure 5).

These results clearly demonstrated that the integration of metB, $y f d Z$ and Pfu-sHSP confers on the Z. mobilis

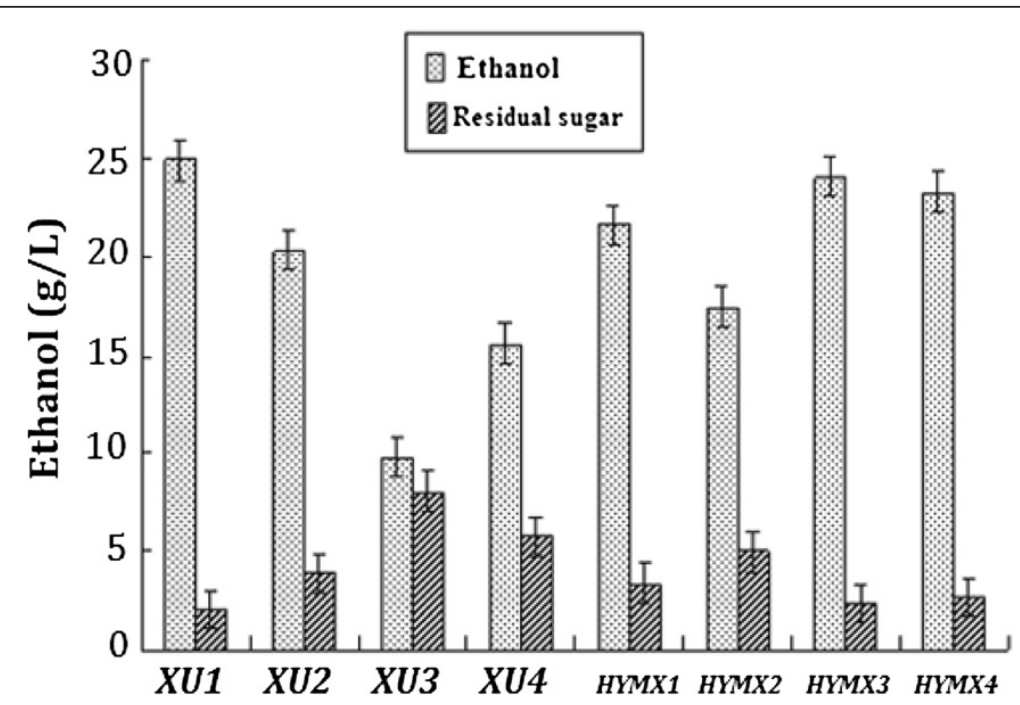

Figure 4 Comparisons of ethanol production and residual sugars of $Z$. mobilis strains in medium when xylose was the only carbon resource. Cultures were grown in RM medium (10 g/L yeast extract, $1 \mathrm{~g} / \mathrm{L} \mathrm{KH}_{2} \mathrm{PO}_{4}, 1 \mathrm{~g} / \mathrm{L}$ Carbamide, $0.5 \mathrm{~g} / \mathrm{L} \mathrm{MgSO}{ }_{4} .6 \mathrm{H}_{2} \mathrm{O}$ ) with $60 \mathrm{~g} / \mathrm{L}$ xylose as the only carbon source under anaerobic conditions at $32^{\circ} \mathrm{C}$. All strains were tested by three parallel experiments. After 60 hours fermentation, ethanol production of all strains was measured immediately by GC. The highest ethanol concentration of XU1 and HYMX3 was $24.9 \mathrm{~g} / \mathrm{L}, 24.1$ $\mathrm{g} / \mathrm{L}$, respectively. 


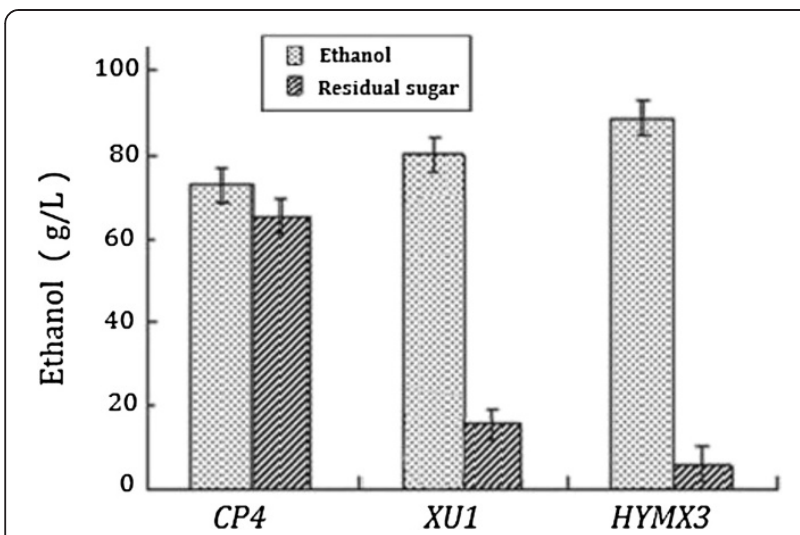

Figure 5 Comparisons of ethanol production and residual sugars between three kinds of $Z$. mobilis strains in medium containing mixed sugars. Cultures were grown in RM medium (10 g/L yeast extract, $1 \mathrm{~g} / \mathrm{L} \mathrm{KH}_{2} \mathrm{PO}_{4}, 1 \mathrm{~g} / \mathrm{L}$ Carbamide, $0.5 \mathrm{~g} / \mathrm{L}$ $\mathrm{MgSO}_{4} \cdot 6 \mathrm{H}_{2} \mathrm{O}$ ) with $170 \mathrm{~g} / \mathrm{L}$ glucose and $60 \mathrm{~g} / \mathrm{L}$ xylose as carbon source anaerobically at $32^{\circ} \mathrm{C}$. All strains were tested by three parallel experiments. After 60 hours anaerobic fermentation, the average ethanol concentration of CP4, XU1 and HYMX3 was $72.7 \mathrm{~g} / \mathrm{L}, 83.8 \mathrm{~g} / \mathrm{L}$ and $88.9 \mathrm{~g} / \mathrm{L}$, respectively.

the ability to produce more ethanol, and that the integration of $x y l A / x y l B$ and $t a l B / t k t A$ succeeded in giving a xylose-fermenting Zymomonas.

\section{Significant increasement in ethanol yield at high temperature}

As the Pfu-sHSP from $P$. furiosus could potentially be used to maintain cell viability under unfavorable conditions such as heat shock or chemical treatments, fermentation experiments were performed to compare the fermentation performance of the engineered strains with CP4 at high temperature in the mixed sugar medium $\left(10 \mathrm{~g} / \mathrm{L}\right.$ yeast extract, $1 \mathrm{~g} / \mathrm{L} \mathrm{KH}_{2} \mathrm{PO}_{4}, 1 \mathrm{~g} / \mathrm{L}$ Carbamide, $\left.0.5 \mathrm{~g} / \mathrm{L} \mathrm{MgSO}_{4} \cdot 6 \mathrm{H}_{2} \mathrm{O}\right)$ containing $170 \mathrm{~g} / \mathrm{L}$ glucose and $60 \mathrm{~g} / \mathrm{L}$ xylose. No obvious difference of ethanol production was observed between the mutant and the wild-type Z. mobilis, when fermentation was carried out at normal temperature at $32^{\circ} \mathrm{C}$. Under high temperature up to $40^{\circ} \mathrm{C}$, the stable integration of $P f u$-sHSP showed a significant impact on the ethanol production of $Z$. mobilis from glucose, xylose or mixed sugar. The Pfu-sHSP bearing strain $H Y M X 3$ and $H Y M$ were found to be more potent to produce ethanol than the wild type $C P 4$.

For Z. mobilis strains without Pfu-sHSP, no matter can or cannot use xylose, their average ethanol production decreased more significantly when the temperature was up to $40^{\circ} \mathrm{C}$ from $32^{\circ} \mathrm{C}$. After 60 hours fermentation,the ethanol production of $C P 4, H Y M$ and $H Y M X$ was reduced by $47 \%, 28 \%$ and $31 \%$, respectively. With the $P f u-s H S P$ gene, HYMX3 and HYM demonstrated a significantly improved tolerance to high temperature (Figure 6).

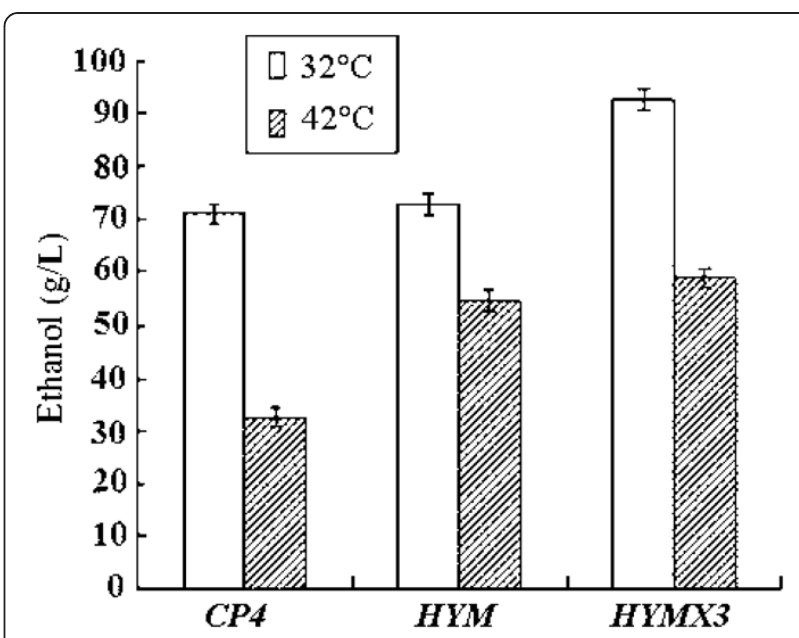

Figure 6 Comparisons of ethanol production between three kinds of $Z$. mobilis strains at different fermentation

temperature. Cultures were grown in RM medium ( $10 \mathrm{~g} / \mathrm{L}$ yeast extract, $1 \mathrm{~g} / \mathrm{L} \mathrm{KH}_{2} \mathrm{PO}_{4}, 1 \mathrm{~g} / \mathrm{L}$ Carbamide, $0.5 \mathrm{~g} / \mathrm{L} \mathrm{MgSO}_{4} \cdot 6 \mathrm{H}_{2} \mathrm{O}$ ) with $170 \mathrm{~g} / \mathrm{L}$ glucose and $60 \mathrm{~g} / \mathrm{L}$ xylose as carbon source at $32^{\circ} \mathrm{C}$ or $42^{\circ} \mathrm{C}$. All strains were tested by three parallel experiments. When the temperature was up to $42^{\circ} \mathrm{C}$ from $32^{\circ} \mathrm{C}$, after 60 hours anaerobic fermentation, the average ethanol production of CP4, HYM and HYMX was reduced by $47 \%, 28 \%$ and $31 \%$, respectively. However, the ethanol production of HYMX3 was still the highest.

\section{Stability test}

Two kinds of chromosomal integrated strains of $Z$. mobilis capable of using xylose were engineered in this research. After preliminary evaluation, strain $X U 1$ and HYMX3 were selected for further stability test and fermentation studies.

Frozen stock culture was transferred into medium $(10 \mathrm{~g} / \mathrm{L}$ yeast extract, $1 \mathrm{~g} / \mathrm{L} \mathrm{KH}_{2} \mathrm{PO}_{4}, 1 \mathrm{~g} / \mathrm{L}$ Carbamide, $0.5 \mathrm{~g} / \mathrm{L}$ $\mathrm{MgSO}_{4} \cdot 6 \mathrm{H}_{2} \mathrm{O}$ ) with $90 \mathrm{~g} / \mathrm{L}$ glucose and $10 \mathrm{~g} / \mathrm{L}$ xylose (RMGX). Overnight grown culture was transferred into an RMGX tube containing $10 \mathrm{~mL}$ of medium with no antibiotic to an initial OD of 0.02 at $600 \mathrm{~nm}$. The inoculum culture was incubated on a rotary shaker at $150 \mathrm{rpm} 32^{\circ} \mathrm{C}$ for 16 hours or until an OD of 2 to 3 at $600 \mathrm{~nm}$ was reached. At the end of 100 generations, the grown culture was tested for fermentation of glucose or xylose, and co-fermentation of glucose with xylose in a $100-\mathrm{mL}$ shake flask containing $80 \mathrm{~mL}$ medium $\left(10 \mathrm{~g} / \mathrm{L}\right.$ yeast extract, $1 \mathrm{~g} / \mathrm{L} \mathrm{KH}_{2} \mathrm{PO}_{4}, 1 \mathrm{~g} / \mathrm{L}$ Carbamide, 0.5 g/L MgSO $4.6 \mathrm{H}_{2} \mathrm{O}, 170 \mathrm{~g} / \mathrm{L}$ glucose, $60 \mathrm{~g} / \mathrm{L}$ xylose). $X U 1$ and $H Y M X 3$ could ferment glucose and xylose, could co-ferment glucose and xylose to produce ethanol with high yield, with no obvious differences than they were first been isolated. The PCR reactions also confirmed that 2 strains were stable up to 100 generations on nonselective medium.

\section{Discussions}

Ethanol production from renewable resources, such as biomass, is a promising alternative to compete with and 
eventually replace nonrenewable fossil fuels; has considerable advantages in terms of sustainability, lower greenhouse gas emissions, and cost reduction. Several groups have tried to develop ethanologenic gram-positive bacteria, but with limited success . However, the gram-negative bacterium $Z$. mobilis is an efficient ethanol producer with favorable features that are at least equal to those from the more familiar yeast. With the recent advances in biotechnology, $Z$. mobilis has the potential to play a key role in making production of ethanol much more economical.

In nature, $Z$. mobilis is found in high sugar content solutions fermenting sugars to ethanol in a high productivity process. It has several advantages over yeast. Ethanol yield of $Z$. mobilis is as high as $97 \%$ of theoretical yield when glucose or fructose is the substrate. It has a high specific ethanol productivity which is up to 2.5 times higher than yeast [12]. It can tolerate up to $400 \mathrm{~g} / \mathrm{L}$ glucose, up to $160 \mathrm{~g} / \mathrm{L}$ ethanol and up to $8 \mathrm{~g} / \mathrm{L}$ acetic acid (at $\mathrm{pH}$ 6) [13]. Its ability to grow at lower $\mathrm{pH}$ (5.0-5.5) helps to reduce the aseptic requirements for fermentation, thus rendering the fermentation process more economical.

The growth of $Z$. mobilis has long been known to require lysine, methionine, and the whole-genome sequencing had revealed the specific reasons for these deficiencies. The only genes missing for lysine and methionine synthesis are $y f d Z$ and $m e t B$, respectively. Herein for the first time, the genome integration of the bi-cistronic $y f d Z$ and met $B$ genes from $E$. coli leaded to a variant of $Z$. mobilis strain can grow in simple chemical defined medium without addition of amino acid.

$P f u$-sHSP is a kind of $\alpha$-crystallin homologues proteins can act as molecular chaperones to prevent membrane destabilization or aggregation of denatured proteins under heat and other stress. Therefore it can potentially be used to maintain cell viability under unfavorable conditions, such as heat shock or chemical treatments. The Pfu-sHSP gene containing bacteria showed an significantly improved tolerance to high temperature in this research.

Several factors prevent the commercial usage of $Z$. mobilis in cellulosic ethanol production. The foremost hurdle is that its substrate range is limited to glucose, fructose and sucrose. Wild-type $Z$. mobilis cannot ferment C5 sugars like xylose which are important components of lignocellulosic hydrolysates. National Renewable Energy Laboratory (NREL) has made significant contributions in expanding its substrate range by introducing xylose metabolizing genes $(x y l A, x y l B, t k t A$ and talB) from $E$. coli into $Z$. mobilis to enable the bacteria to ferment xylose [14]. This technique succeeded in giving a xylose-fermenting Zymomonas. Here, we demonstrated a unique strategy to allow efficient co-fermentation of glucose and xylose by Z. mobilis. A strong promoter (fusion of 2 strong constitutive promoters of $Z$. mobilis) was cloned to facilitate the higher level expression of genes under its control. Under the control of this strong promoter, the over expression of xylose utilization pathway seems to work efficiently. Our research results showed that the ethanol yield of the mutant $Z$. mobilis HYMX3 is as high as $0.415 \mathrm{~g}$ per gram of xylose when $60 \mathrm{~g} / \mathrm{L}$ xylose is the only carbon source, corresponding to $81.2 \%$ of theoretical yield.

Researchers usually use shuttle plasmid to transform bacteria. Although plasmids may be readily maintained in Z. mobilis when cultivated in mono-culture under controlled conditions, they frequently become unstable when grown in the absence of antibiotic selection pressure. Instability may be exacerbated when $Z$. mobilis has to compete with other organisms in a mixed culture. In addition, antibiotic usage for plasmid maintenance is generally perceived as undesirable for industrial application. Thus, it is preferable to integrate the cloned DNA into the $Z$. mobilis genome where they are maintained at a low natural copy number and are thus not overexpressed, and where, at least theoretically, they should be as stable as genome DNA.

As low-cost industry fermentations may always be carried out in rather poor, toxic, viscous, nutrient-limited medium, successful fermentations from lignocelluloses to produce ethanol using $Z$. mobilis require not only the capability to convert mixed sugars to ethanol with high yield, but also the tolerance to stresses such as high temperature and low nutritional condition. These cellular characteristics are important, because current methods for pretreatment of lignocelluloses generate a mixture of sugars, primarily glucose and xylose; and because high temperature in summer and low nutritional concentration at the end of a batch are common in the ethanol industry.

\section{Conclusions}

In this research, seven foreign genes $(y f d Z$, metB, $x y l A$, $x y l B, t k t A$ and talB from $E$. coli, Pfu-sHSP from $P$. furiosus) were integrated into the genome DNA of CP4 to create the Z. mobilis HYMX3 through Tn5 transposon mediated transposition. The recombinant strain $H Y M X 3$ has the following characteristics listed bellow at the same time: can grow in simple chemical defined medium without adding any kinds of amino acid; can ferment both glucose and xylose to produce ethanol with high productivity; having high tolerance to high temperature and low nutrient; the fermentation characteristics were stable up to 100 generations on nonselective medium. Although significant improvements were achieved, yeast extract is needed for ethanol production.

Our results demonstrated that $H Y M X 3$ can be an alternative bio-ethanol producer for ethanol production 
from lignocelluloses which is much less sensitive to temperature and nutrition changes.

\section{Materials and methods}

\section{Bacterial strains and cultural conditions}

The bacterial strains and plasmids used are listed in Table 2. The E. coli K12 MG1655 was from the American Type Culture Collection (ATCC), was grown on Luria- Bertani (LB). P. furious strain was from ATCC, its genomic DNA was used as template for PCR amplification of the PfusHSP gene. Z. mobilis ATCC 31821 (CP4) from ATCC was used as the template for PCR amplification of the promoter of glycelaldehyde- 3-phosphate dehdyrogenase (PGAP) and enolase (PENO) [5].

Z. mobilis strains were cultivated anaerobically in RM medium $\left(10 \mathrm{~g} / \mathrm{L}\right.$ yeast extract, $1 \mathrm{~g} / \mathrm{L} \quad \mathrm{KH}_{2} \mathrm{PO}_{4}, 1 \mathrm{~g} / \mathrm{L}$ Carbamide, $0.5 \mathrm{~g} / \mathrm{L} \mathrm{MgSO}_{4} \cdot 6 \mathrm{H}_{2} \mathrm{O}$ ) at $32^{\circ} \mathrm{C}$, supplemented with different amounts of glucose or xylose (as indicated) as carbon source. For the inoculum preparation, a single colony was added to a test tube containing $5 \mathrm{~mL} \mathrm{RM}$ broth and cultured aerobically at $32^{\circ} \mathrm{C}$ until it reached late exponential or early stationary phase. A 1/100 dilution was added into the pre-warmed RM broth $(10 \mathrm{~mL}$ culture into $1000 \mathrm{~mL} \mathrm{RM}$ ), which was then cultured aerobically at $32^{\circ} \mathrm{C}$ with shaking at $100 \mathrm{rpm}$ for approximately $60 \mathrm{~h}$. The optical density was measured with a spectrophotometer at $600 \mathrm{~nm}$. Fermentation medium and fermentation products from filter-sterilized cell-free spent medium were compositionally analyzed by gas chromatography for ethanol determinations. The reducing sugar concentration was determined using the DNS method [15].

Table 2 Bacterial strains and plasmids used in this study

\begin{tabular}{|c|c|c|}
\hline Strains & Containing genes & source \\
\hline E. coli K12 MG1655 & $x y|A, x y| B, t k t A, t a \mid B, y f d Z$, metB & $\begin{array}{l}\text { ATCC } \\
47076\end{array}$ \\
\hline P. furious & Pfu-sHSP & $\begin{array}{l}\text { ATCC } \\
43587\end{array}$ \\
\hline Z. mobilis CP4(CP4) & Wild-type Z. mobilis & $\begin{array}{l}\text { ATCC } \\
31821\end{array}$ \\
\hline Z. mobilis $X U(X U)$ & $x y|A, x y| B, t k t A, t a l B$ & This study \\
\hline Z. mobilis HYM(HYM) & yfdZ, metB, Pfu-sHSP & This study \\
\hline $\begin{array}{l}\text { Z. mobilis HYMX } \\
(H Y M X)\end{array}$ & $\begin{array}{l}\text { yfdZ, metB, Pfu-sHSP, xylA, xylB, tktA, } \\
\text { talB }\end{array}$ & This study \\
\hline \multicolumn{3}{|l|}{ Plasmids } \\
\hline pTN-HMY & Pfu-sHSP, metB, yfdz & This study \\
\hline pTN-XU & $x y|A, x y| B$, tktA, talB & This study \\
\hline PTN -HMYX & $\begin{array}{l}\text { yfdZ, metB, Pfu-sHSP, xylA, xylB, tktA, } \\
\text { talB }\end{array}$ & This study \\
\hline
\end{tabular}

$y f d Z$ and $m e t B$ genes were used for self-synthesizing lysine and methionine; $x y|A, x y| B, t k t A$ and $t a l B$ genes were used for utilizing xylose to produce ethanol;

Pfu-sHSP gene was used for increasing the tolerance to heat stresses.

\section{Gas chromatography (GC)}

Ethanol concentration in the medium supernatant was determined by flame ionization gas chromatography. Culture samples $(1 \mathrm{~mL})$ and standards were prepared by filtration. The samples and standards were quantified by injecting $1 \mu \mathrm{L}$ of each into a model 6890 Agilent Technologies, equipped with a DB-FFAP $30 \mathrm{~m} \times 0.53 \mathrm{~mm} \times$ $1.5 \mu \mathrm{m}$ film thickness capillary column (Agilent, Santa Clara, CA). The column operated with an initial temperature of $80^{\circ} \mathrm{C}$ and ramping $10^{\circ} \mathrm{C}$ to a final temperature of $180^{\circ} \mathrm{C}$, while detector was at $250^{\circ} \mathrm{C}$ and injector temperature was $200^{\circ} \mathrm{C}$ with a post-injection dwell time of one minute. The carrier gas was $\mathrm{N}_{2}$ at a constant flow rate of $5 \mathrm{~mL} / \mathrm{min}$.

\section{Construction of $\operatorname{Tn} 5$ transposon vector and transposome preparation}

Promoter PGAP/ENO was a fusion of 2 strong constitutive promoters of $Z$. mobilis, promoter glyceraldehyde3-phosphate dehydrogenase (PGAP) and promoter 2-phosphoglycerate dehydratase (PENO). Promoter PGAP was amplified from $Z$. mobilis chromosomal DNA with the primer pair: 5' ctcgagGTTCGATCAACAACCCGAA TCCTA and $5^{\prime}$ ggatcCCTAACTTATTAAGTAGCTATT ATATTC; Promoter PENO was amplified with the primer pair: 5' agatctCTCCAGTTACTCAATACGTAAC and 5' gaattcAACCTTTCTTAAAATCTTTTAGACG. After the PGAP DNA was digested with BamHI and the PENO DNA was digested with BglII,two DNA fragments were mixed, heated at $72^{\circ} \mathrm{C}$ for $60 \mathrm{~min}$, and incubated with $\mathrm{T} 4$ DNA ligase for an additional 12 hours at $18^{\circ} \mathrm{C}$ to form the fusion PGAP/ENO promoter. The fusion promoter was PCR amplified with primer: $5^{\prime}$ ctcgagGTTCGATCAACA ACCCGAATCCTA and $5^{\prime}$ gaattcAACCTTTCTTAAAA TCTTTTAGACG.

The $y f d Z$ gene was amplified from E. coli $\mathrm{K}-12$ chromosomal with the primer pair: $5^{\prime}$ gaattcATGGCT GACACTCGCCCTGAACGT and 5' gtcgacTTATTCCG CGTTTTCGTGAATATG. After the digestion by EcoRI, this $1.3 \mathrm{~kb}$ DNA fragment was ligated with the EcoRI fragment of PGAP/ENO to form the $Z$. mobilis expressible PGAP/ENO-yfdZ operon. The metB gene was amplified from E. coli $\mathrm{K}-12$ chromosomal with the primer pair: 5' gaattcATGACGCGTAAACAGGCCACCAT and $5^{\prime}$ gtcgacTTACCCCTTGTTTGCAGCCCGGAA. After the digestion by EcoRI, this $1.17 \mathrm{~kb}$ DNA fragment was ligated with the EcoRI fragment of PGAP/ENO to form the $Z$. mobilis expressible PGAP/ENO-metB operon. The $P f u-s H S P$ gene was amplified from $P$. furious chromosomal DNA with the primer pair: 5' gaattcATGGTGA GGAGAATAAGAAGATG and $5^{\prime}$ gtcgacTTATTCAAC TTTAACTTCGAATCCTTC. After the digestion by EcoRI, this $0.5 \mathrm{~kb}$ DNA fragments was ligated with the EcoRI fragment of PGAP/ENO to form the PGAP/ENO- 
sHSP operon. After the PGAP/ENO-metB operon was digested with SalI and the PGAP/ENO-yfdZ operon was digested with XhoI, two DNA fragments were ligated to get the PGAP/ENO-metB/yfdZ operon. After PGAP/ $E N O-m e t B / y f d Z$ operon was digested with XhoI and PGAP/ENO-sHSP operon was digested with SalI, two DNA fragments were ligated to result in the PGAP/ ENO-sHSP/metB/yfdZ operon which could be cut out by SalI and Xhol (Figure 7).

The commercial EZ-Tn5 pMOD vector was modified by substituting the PvuI and PshAI restriction sites outside of both ends flanking Tn5 transposase recognition sequences with SfiI restriction site. The resulting plasmid was named as pTN, is a high-copy number, pUC19based vector contains a multiple cloning site (MCS) between the hyperactive 19 bp Mosaic Ends (ME) that is specifically and uniquely recognized by $\operatorname{Tn} 5$ Transposase. Tn5-carrying plasmid pTN was modified further for integration of foreign DNA into Z. mobilis. The tetracycline resistance gene which was mutated without SalI restriction site (from the $1.4 \mathrm{~kb}$ BamHI fragment from p34S-Tc,
Genebank: AF062082) was inserted into the BamHI site of plasmid pTN to result in the plasmid pTN-TC. The PGAP/ENO-sHSP/metB/yfdZ operon was obtained by digestion with SalI and XhoI, was inserted into the SalI site of pTN-TC. The resulting plasmid, designated as pTNHMY (Figure 8), was then transformed into chemically competent E. coli Top10 cells (Invitrogen) and inoculated onto LB agar plates supplemented with tetracycline and ampicillin and sequence confirmed.

To prepare the transposome, the $\mathrm{Tn} 5$ transposon pTN-HYM was digested with SfiI. The $6.9 \mathrm{~kb}$ was purified from the agarose gel, and mixed with EZ-Tn5 transposase (Epicentre). The mixture was incubated for $30 \mathrm{~min}$ at room temperature, to allow the transposase to stably bind to the Tn5 Transposon DNA; that mixture was then stored at $-20^{\circ} \mathrm{C}$.

The $x y l A / x y l B$ genes were amplified from E. coli $\mathrm{K}-12$ chromosomal with the primer pair: $5^{\prime}$ gaattcATGCAAG CCTATTTTGACCAGC and $5^{\prime}$ gtcgacTTATTTGTCG AACAGATAATGGTTT. After the deletion of the SalI restriction site within the $x y l A$ gene by mutagenesis, this

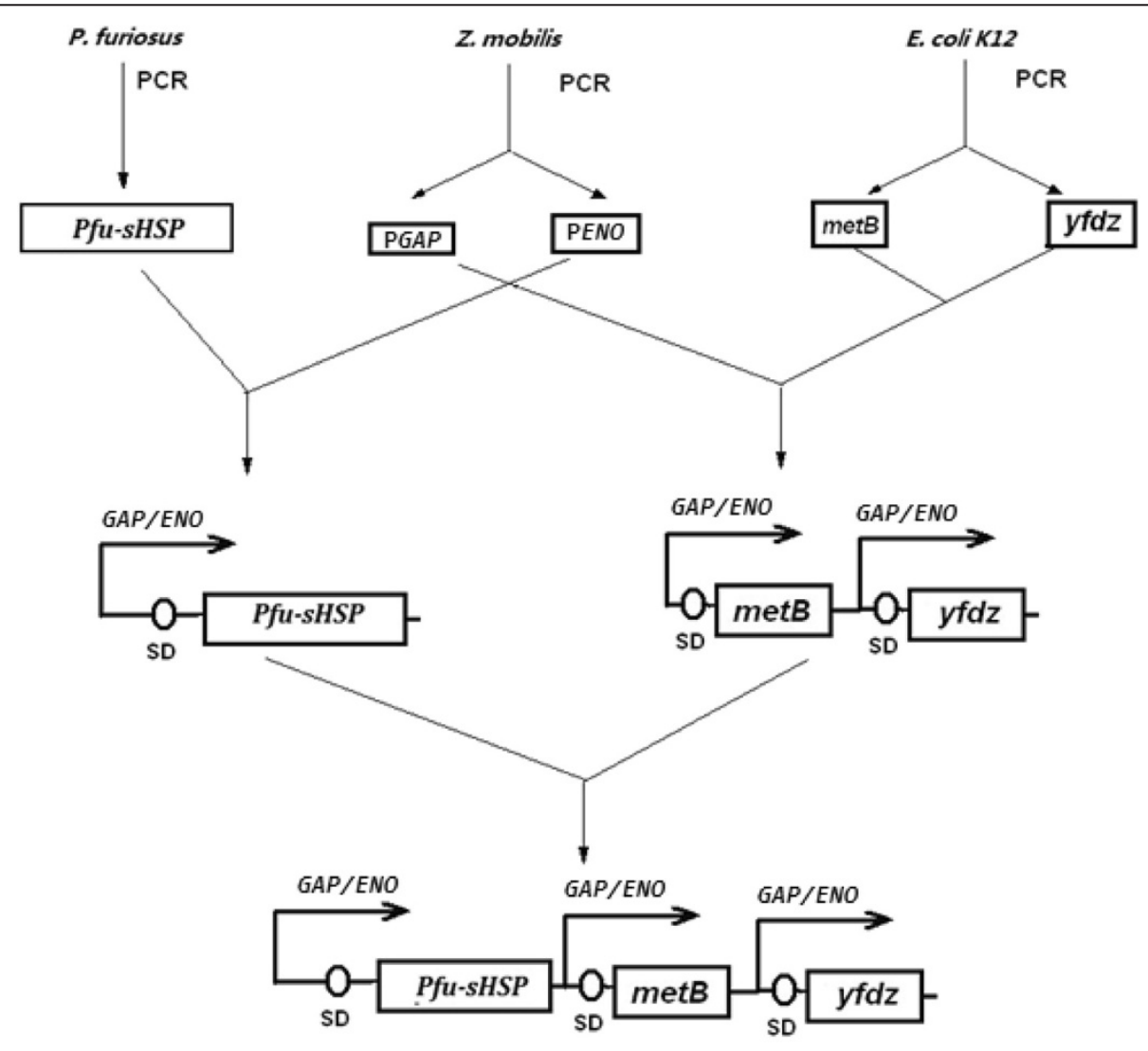

PGAP/NEO-sHSP/metB/yfdZ

Figure 7 Constructions of PGAP/NEO-sHSP/metB/yfdZ. A fusion promoter (fusion of 2 strong constitutive promotors: PGAP and PNEO from $Z$. mobils) was cloned to facilitate the higher level expression of genes under its control. The $y f d Z$ and metB genes were used to decrease nutritional requirements. The Pfu-sHSP gene was used to increase resistance to heat stress. 


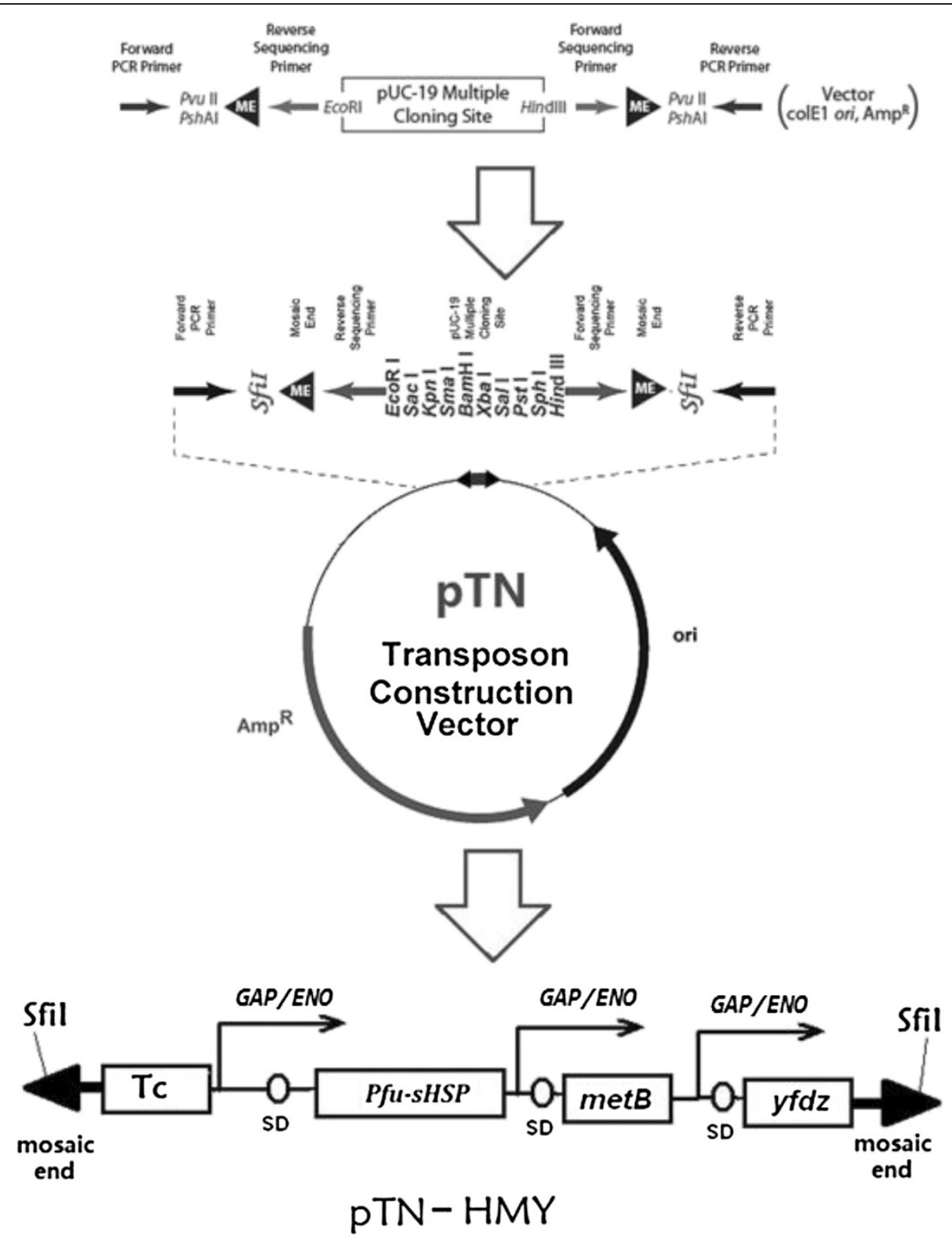

Figure 8 Constructions of Tn5 transposon - pTN-HMY. Commercial EZ-Tn5 pMOD vector was mutated to create vector pTN by substituting the Pvul and PshAl with Sfil restriction site. To allow selection of Z. mobilis transformants after electroporation with the Tn5 transposon, tetracycline resistance determinant (TC) was cloned into the multiple cloning site in the vector PTN. The sHSP/metB/yfdZ operon was cloned into the Sall site of PTN to create PTN-HYM. This plasmid contains Sfil restriction site recognized sequences flanking the mosaic end (ME) sites, which are specifically recognized by the EZ-Tn5 transposase.

$2.87 \mathrm{~kb}$ DNA fragments were digested with EcoRI, and was ligated with the EcoRI fragment of PGAP/ENO to form the PGAP/ENO-xylA/xylB operon. The talB/tktA genes were amplified from E. coli K-12 chromosomal with the primer pair: $5^{\prime}$ gaattcATGACGGACAAATTGA CCTCCCTTC and $5^{\prime}$ gtcgacTTACAGCAGTTCTTTTG CTTTC. After the deletion of the SalI restriction site within the $t k t A$ gene by mutagenesis, this $2.97 \mathrm{~kb}$ DNA fragments were digested with EcoRI, and was ligated with the EcoRI fragment of PGAP/ENO to form the $Z$. mobilis expressible PGAP/ENO-talB/tktA operon. After the PGAP/ENO-xylA/xylB operon were digested with XhoI and PGAP/ENO-talB/tktA operon was digested with SalI, two fragments were ligated to form the PGAP/ ENO- $x y l A / x y l B / t a l B / t k t A$ operon which could be cut out by SalI and XhoI (Figure 9).

After the digestion with SalI and XhoI, the PGAP/ENO$x y l A / x y l B / t a l B / t k t A$ operon was recovered, and was inserted into the Sall site of pTN-TC. The resulting plasmid, named pTN-XU (Figure 10), was then transformed 


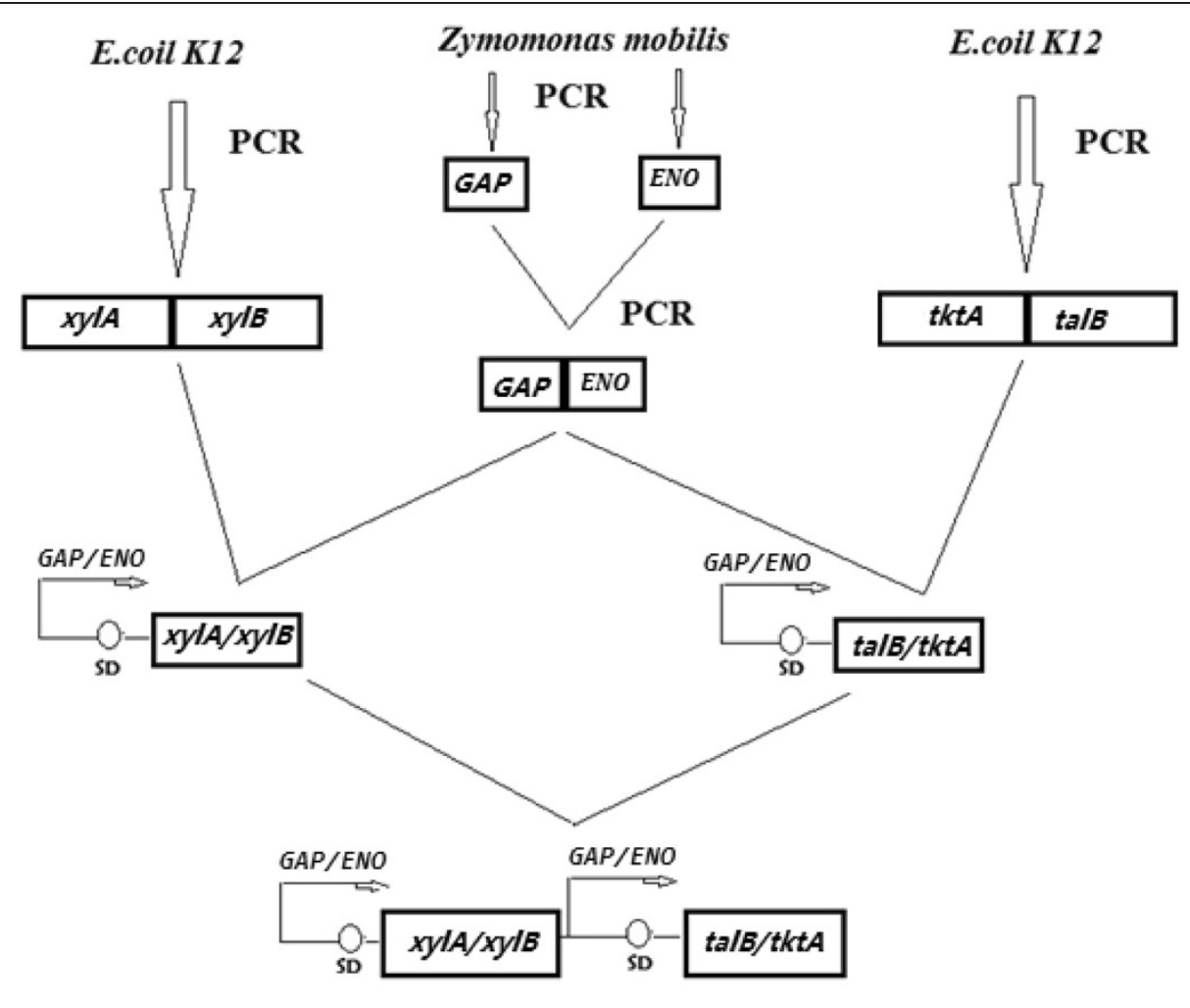

$\mathrm{PGAP} / \mathrm{NEO}-\mathrm{xylA} / \mathrm{xylB} / \mathrm{talB} / \mathrm{tktA}$

Figure 9 Constructions of PGAP/NEO-xyIA/xylB/talB/tktA. A fusion promoter was cloned to facilitate the higher level expression of genes under its control. The $x y|A| x y \mid B$ and the talB/tktA operons were used to add a metabolic pathway to utilize xylose to produce ethanol.

into chemically competent E. coli Top10 cells (Invitrogen) and inoculated onto LB agar plates supplemented with tetracycline or ampicillin. The whole PGAP/ENO-sHSP/ $m e t B / y f d Z$ operon was obtained by digestion with SalI and XhoI, was inserted into the SalI site of pTN-XU. The resulting plasmid, designated as pTN-HMYX (Figure 11).

After determining that $Z$. mobilis $C P 4$ was indeed sensitive to tetracycline, fresh electrocompetent cells were prepared by washing cells from $400 \mathrm{ml}$ of a broth culture (RM medium) at an optical density at $600 \mathrm{~nm}$ (OD600) of 0.4 twice with equal volumes of ice-cold $10 \%$ glycerol. Cells were suspended again in $400 \mathrm{ul}$ of washing buffer, and aliquots of $100 \mathrm{ul}$ were dispensed into 0.2-mm gapped electroporation cuvettes along with $1 \mathrm{ul}$ of pTN-HYM -Tn5 mixture. Electroporation was performed with a Bio-Rad Gene Pulser Xcell $(6.0 \mathrm{~ms}, 1.5 \mathrm{kV})$. Cells were immediately diluted in $1 \mathrm{ml} \mathrm{RM}$ medium and plated onto RM agar supplemented with $30 \mathrm{ug} / \mathrm{ml}$ tetracycline.

After 2 days of incubation at $32^{\circ} \mathrm{C}$, colonies on tetracycline-containing plates arose only when the Electroporation mixtures had contained pTN-HYM; not a single colony was observed in the mixtures without DNA. From three independent transformations, we picked 100 random colonies and those cells were used to inoculate in fresh

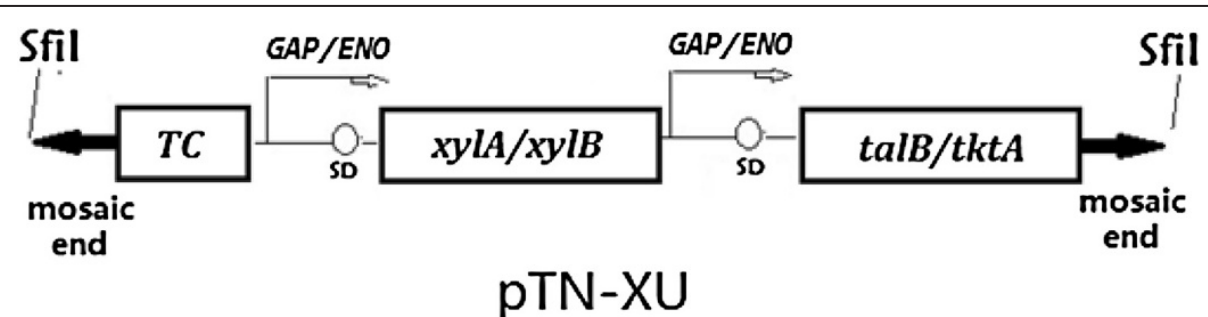

Figure 10 Generation of Tn5 transposon vector $\mathbf{p T N}-X U$ for random mutagenesis of $Z$. mobilis. The $x y \mid A / x y / B / t a / B / t k t A$ operon for adding a metabolic pathway for Z. mobilis to utilize xylose was inserted into the Sall site to create PTN-XU. This plasmid contains Sfil recognized sequences flanking the mosaic end (ME) sites, which are specifically recognized by the EZ-Tn5 transposase. 


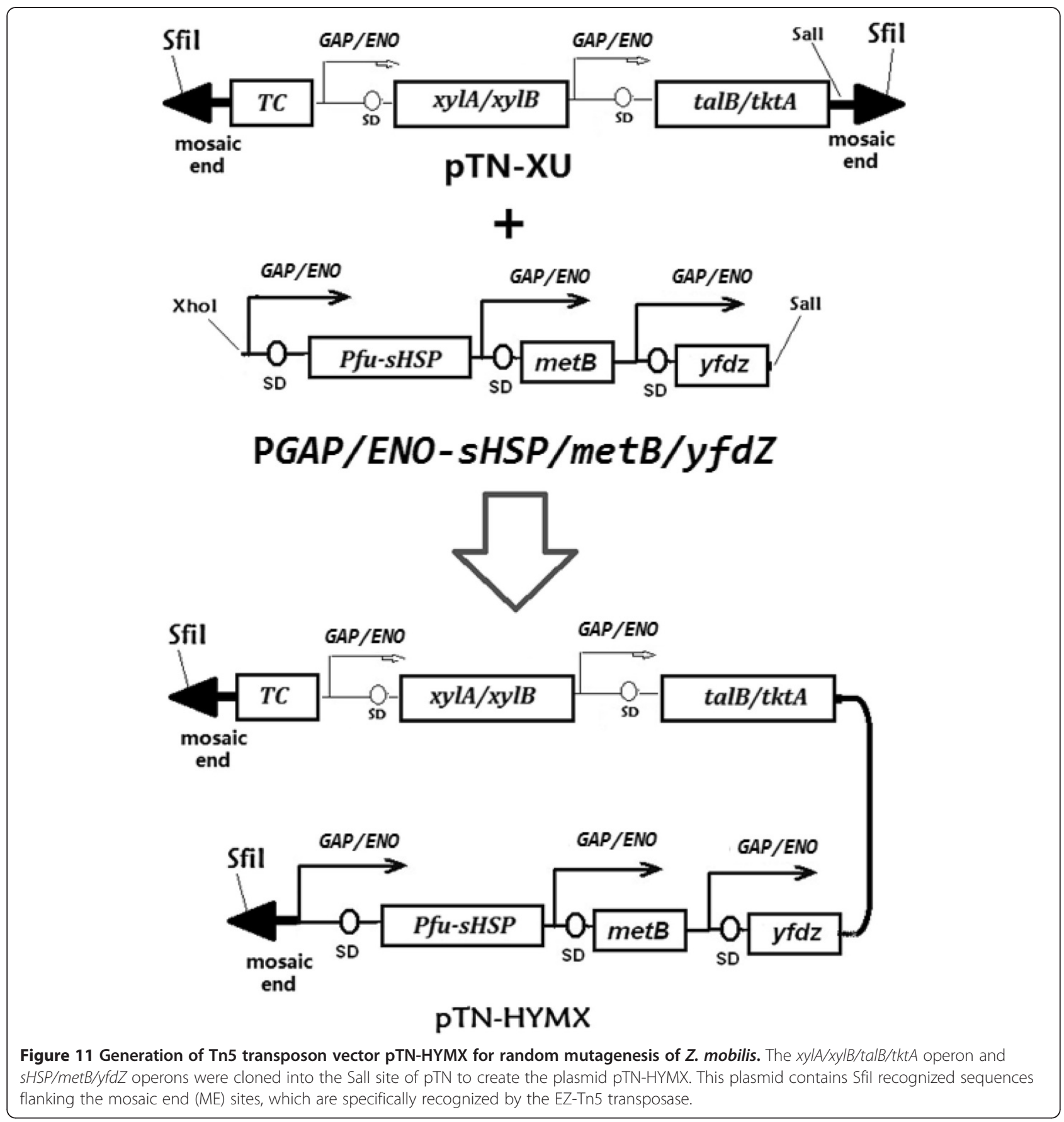

RM liquid medium. To verify Tn5 integration, DNA was isolated using the Qiagen DNeasy blood and tissue kit, and $\mathrm{Tn} 5$ insertion within the genome were analyzed by PCR.

Development of recombinant $Z$. mobilis with xylose utilization capability

Two kinds of transposome mixture (pTN-XU and pTNHYMX) were electroporated into CP4. To prepare the transposome, pTN-XU or pTN-HYMX was digested with Sfil, so that the xylose-utilizing operon could be purified from an agarose gel, and mixed with EZ-Tn5 transposase (Epicentre). The mixture was incubated for $30 \mathrm{~min}$ at room temperature, to allow the transposase to bind stably to the Tn5 Transposon DNA; that mixture was then stored at $-20^{\circ} \mathrm{C}$.

Fresh CP4 electrocompetent cells 100 ul were dispensed into $0.2-\mathrm{mm}$ gapped electroporation cuvettes along with 1 ul of DNA-Tn5 transposase mixture. 
Electroporation was performed with a Bio-Rad Gene Pulser Xcell $(6.0 \mathrm{~ms}, 1.5 \mathrm{kV})$. Cells were immediately diluted in $1 \mathrm{ml}$ RM medium and plated onto agar supplemented with $50 \mathrm{ug} / \mathrm{ml}$ tetracycline and xylose as the only carbon source. After 2 days incubation at $32^{\circ} \mathrm{C}$, colonies on tetracycline -containing plates arose only when the electroporation mixtures had contained DNA from pTN-XU or pTN-HYMX; not a single colony was observed in the mixtures without DNA. A total of about $6 \times 10^{2}$ tetracycline (Tc)-resistant transformants were obtained in each of three independent transformation experiments with CP4. Colony from pTN-HYMX was designated as Z. mobilis HYMX (HYMX), and colony from pTN-XU designated as Z. mobilis XU $(X U)$. From three independent transformations, we picked 50 random $H Y M X$ colonies and 50 random $X U$ colonies. These cells were used to inoculate in fresh RM liquid medium. To verify DNA integration, $Z$. mobilis DNA was isolated using the Qiagen DNeasy blood and tissue kit, and were analyzed by PCR. PCR identification showed that, 92 from the above 100 strains had the associated genes been fully integrated into the genome. Strains with higher ethanol production were selected for further fermentation research.

\section{Competing interests}

The authors declare that they have no competing interests.

\section{Authors' contributions}

HW and XJ set up and designed the study. WZ, TW and XJ cloned the plasmids and transposon; XZ, TW and WZ performed the characterization of selected strains. XZ, WZ and TW performed GC experiments; HW, XZ analyzed the data and wrote the manuscript. All authors discussed the results and commented on the manuscript, and all authors read and approved the final manuscript.

\footnotetext{
Acknowledgments

We gratefully acknowledge financial support from the National Natural Science Foundation of China (NSFC) (project no. 30870798), Hubei Provincial Innovative Research Team in University (Project No. T200705), the Scientific Research Key Project of Hubei Provincial Department of Education (project no. Z200614001). Haoyong Wang also thanks the Scientific Research Foundation for the Returned Overseas Chinese Scholars (Ministry of Personnel, State Education Ministry and Hubei Provincial Department of Personnel).
}

\section{Author details \\ ${ }^{1}$ Key Laboratory of Fermentation Engineering (Ministry of Education), Hubei Provincial Key Laboratory of Industrial Microbiology, College of Bioengineering, Hubei University of Technology, Wuhan 430068, China. ${ }^{2}$ Nanhu Middle School, Wuhan 430060, China. ${ }^{3}$ Zhejiang Hisun Pharmaceutical Co., Ltd., Taizhou 318000, China.}

Received: 11 February 2013 Accepted: 29 April 2013

Published: 2 May 2013

\section{References}

1. Skotnicki ML, Lee KJ, Tribe DE, Rogers PL: Genetic alteration of Zymomonas mobilis for ethanol production. Basic Life Sci 1982, 19:271-290.

2. Skotnicki ML, Warr RG, Goodman AE, Lee KJ, Rogers PL: High- productivity alcohol fermentations using Zymomonas mobilis. Biochem Soc Symp 1982, 19:53-86.
3. Laksanalamai P, Maeder DL, Robb FT: Regulation and mechanism of action of the small heat shock protein from the hyperthermophilic archaeon Pyrococcus furiosus. J Bacteriol 2001, 183:5198-5202.

4. Laksanalamai P, Jiemjit A, Bu Z, Maeder DL, Robb FT: Multisubunit assembly of the Pyrococcus furiosus small heat shock protein is essential for cellular protection at high temperature. Extremophiles 2003, 7(1):79-83.

5. Burnett ME, Liu J, Conway T: Molecular characterization of the Zymomonas mobilis enolase (eno) gene. J Bacteriol 1992, 174:6548-6553.

6. Jeffries TW: Ethanol fermentation on the move. Nat Biotechnol 2005, 23(1):40-41.

7. Widiastuti H, Kim JY, Selvarasu S, Karimi IA, Kim H, Seo J-S, Lee D-Y: Genome-scale modeling and In Silico analysis of ethanologenic bacteria Zymomonas mobilis. Biotechnol Bioeng 2010, 108(3):655-665.

8. Seo J-S, Chong H, Park HS, Yoon K-O, Jung C, Kim JJ, Hong JH, Kim H, Kim J-H, Kil J-I, Park CJ, Oh H-M, Lee J-S, Jin S-J, Um H-W, Lee H-J, Oh S-J, Kim JY, Kang HL, Lee SY, Lee K, Kang HS: The genome sequence of the ethanologenic bacterium Zymomonas mobilis ZM4. Nat Biotechnol 2005, 23:63-68.

9. Lawford HG, Rousseau JD: The effect of glucose on high-level xylose fermentations by recombinant Zymomonas in batch and fed-batch fermentations. Appl Biochem Biotechnol 1999, 77-9:235-249.

10. Lawford HG, Rousseau JD: Comparative energetics of glucose and xylose metabolism in recombinant Zymomonas mobilis. Appl Biochem Biotechnol 2000, 84-6:277-293.

11. Goryshin IY, Reznikoff WS: Tn5 in vitro transposition. J Biol Chem 1998, 273:7367-7374

12. Nichols NN, Dien BS, Bothast RJ: Engineering lactic acid bacteria with pyruvate decarboxylase and alcohol dehydrogenase genes for ethanol production from Zymomonas mobilis. J Ind Microbiol Biotechnol 2003, 30:315-321. 19.

13. Talarico LA, Gil MA, Yomano LP, Ingram LO, Maupin-Furlow JA: Construction and expression of an ethanol production in gram-positive bacteria. Microbiology 2005, 151:4023-4031.

14. Zhang M, Eddy C, Deanda K, Finkelstein M, Picataggio S: Metabolic engineering of a pentose metabolism pathway in ethanologenic Zymomonas mobilis. Sci 1995, 267:240-243.

15. Miller GL: Use of dinitrosalicylic acid reagent for determination of reducing sugar. Anal Chem 1959, 3:426-428.

doi:10.1186/1475-2859-12-41

Cite this article as: Zhang et al.: Use of a Tn5-based transposon system to create a cost-effective Zymomonas mobilis for ethanol production from lignocelluloses. Microbial Cell Factories 2013 12:41.

\section{Submit your next manuscript to BioMed Central and take full advantage of:}

- Convenient online submission

- Thorough peer review

- No space constraints or color figure charges

- Immediate publication on acceptance

- Inclusion in PubMed, CAS, Scopus and Google Scholar

- Research which is freely available for redistribution

Submit your manuscript at www.biomedcentral.com/submit
C Biomed Central 